\title{
Tariffs In Apparel And Footwear: A Gender Approach
}

\author{
Uros Andrejevic, Consultant Goldman Sachs \\ Giuliana Campanelli Andreopoulos, William Paterson University, USA \\ Alexandros Panayides, William Paterson University, USA
}

\begin{abstract}
The theory of tariffs is very different from the reality of tariffs. Most of the literature on protectionism is too theoretical and, more importantly, too aggregate. In practice, tariffs greatly differ among products and affect consumers differently based on their income and gender. In this paper we use a gender approach to study US tariffs on selected apparel and footwear products. The scope of this study is to examine whether gender plays a role in evaluating the cost of tariffs on consumers and to suggest policies to end a possible discriminatory conduct.
\end{abstract}

\section{INTRODUCTION AND SUMMARY OF THE LITERATURE}

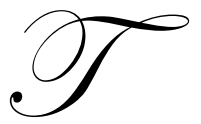

he discussion on tariffs has been very animated in academia and media over the last decade. The main shortcoming of this discussion is that is too theoretical and, more importantly, too aggregate. In practice tariffs greatly differ among products and consumers are affected differently based on their income and gender. In a previous study we have shown that the current US tariff system on apparel and footwear appears to be ineffective as a tool of protectionism and act as a regressive taxation upon the poor, Andrejevic et. al. (2006). In this paper we extend our investigation by using a gender approach to study tariffs on selected apparel and footwear products and to suggest policies to end a possible discriminatory conduct.

As we have discussed in our previous study Andrejevic et. al (2006), the standard analysis of tariffs analyzes their effects by using the consumer and producer surplus. The basic result is that tariffs redistribute income from domestic consumers who pay a higher price for the commodity to domestic producers who receive the higher price and the government who collects revenue from tariffs. This leads to inefficiency that is referred as the protection or deadweight loss of the tariff. In this type of analysis the emphasis is on the inefficiency of the system and the calculation of the welfare effects. Consumers are taken as a whole, without distinguishing between low and high income consumers and consequently this type of literature does not address the redistributive effect of tariffs among consumers. The only exceptions to this approach are the contributions of Gresser (2002a, b) and Andrejevic et. al (2006) which distinguish between different types of consumers and different types of products. A more serious shortcoming of the literature on protectionism is the lack of reference to gender with the exception of a limited discussion in the media, Barbaro (2007). In this paper we try to address this shortcoming by extending our previous analysis on apparel and footwear to understand the role of gender.

The paper is constructed as follows. Section one provides an introduction and summary of the literature, section two deals with the tariff system in apparel and footwear, section three studies tariffs in footwear and apparel by using a gender approach. Section four provides policy recommendations and finally section five summarizes the main conclusions.

\section{THE TARIFF SYSTEM IN APPAREL AND FOOTWEAR}

Since the 1960 tariffs on industrial products have been dramatically reduced. In 2002, the average ad valorem tariff on all goods was $1.6 \%$ Gresser (2002a). However, this overall average does not show the actual pattern of tariffs. Particularly, tariffs on natural resources (oil, metal ores) and farm products (coffee and chocolate) 
are usually zero or minimal; tariffs on high-tech consumer goods (computers, airplanes, and medical equipment) have been progressively eliminated while tariffs on low technology consumer products (apparel and footwear) still remain extremely high. Thus, authors such as Gresser (2002a) claim that the US has a two tariff system, one for lowtech consumer goods with an average rate of $10.5 \%$ and the other (for everything else) with an average rate of $0.8 \%$. In this paper we focus our attention on footwear and apparel where the average tariff is $11.4 \%$ and generated total tariff revenue of $46.7 \%$.

As we have shown in our previous study Andrejevic et. al (2006) the above average tariff on apparel and footwear was not able to protect either employment or output. The reduction in employment on both sectors is striking similar: -66\% in footwear and -65\% in apparel between 1995 and 2004. Turning to output, the data show a negative trend in both sectors. However, the reduction in output in footwear is much more pronounced: $-89.9 \%$ between 1995 and 2003 versus $-60.05 \%$ in apparel between 1997 and 2004. Needless to say, these results can be explained with the competition coming from Asian countries where costs, particularly labor cost, are much lower.

Moreover, tariffs on apparel and footwear hit low income consumers, since they spend a disproportionate percentage of their income on necessities, Andrejevic et. al (2006) and Grasser (2002a). In addition to income, there is a gender issue concerning the tariffs on apparel and footwear which, as stated above, has not been properly addressed and needs further investigation.

\section{A GENDER APPROACH TO APPAREL AND FOOTWEAR TARIFFS}

The main question addressed in this section is: Is there a gender difference in the U.S. tariff system for apparel and footwear and how can it be explained? Before answering this question, one preliminary point needs to be clarified. Our investigation is at product level and we compare products disaggregated by gender. The disaggregation of these products is mainly based of their final use, as well as the material employed to produce them.

Table 1 summarizes the main results of our empirical investigation ${ }^{1}$. As one can see from the table, the main results are the following two.

1) Gender difference in tariffs plays a role at product level. In the case of footwear there is a limited pattern of divergence of 1.5 percentage points with the only exception of golf shoes. In the case of apparel the gender divergence, however, is greater and can reach extremely high figures: 16 percentage points in the case of swimwear followed by 15.6 and 13.3 percentage points for suits of various synthetic fiber compositions. It is worth adding that in the case of footwear, women are penalized whereas in the three apparel cases, men are.

2) Out of the twenty two products examined, sixteen of them exhibit higher tariff rates for women. In very simplistic way we can interpret this result by saying that there is a discrimination against women. However, a full account of the gender discrimination at aggregate level should consider not only the number of products but also the amount of the divergence in the tariff as well as the value of the products.

Turning to the question of the rationality behind the gender discrimination, there are several interpretations. The more simplistic one is "plain old sexism", Barbaro (2007) since the first appearance of gender differences in the tariff system dates back to the mid 1800s. The second most common interpretation is based on the belief that the system is irrational. This position is even supported by the U.S. government. The only opinion of federal regulators on this issue appeared in a 1960 study of the U.S. tariff system in which, discussing the gender disparities on shoes, they claim that "their economic justification is questionable" Barbaro (2007).

\footnotetext{
${ }^{1}$ The table had been constructed as follows: In the case of footwear and leather products, we only reported those products with a gender difference in tariff equal or greater than 1.4, while in the case of apparel, we reported only those products with gender difference equal or higher than 3.4. The products have been listed in ranking order according to the difference in tariff by gender (in absolute terms).
} 
Our interpretation is different. We think that the maintenance of the above average tariff in apparel and footwear as well as the gender differences are the results of an interaction between the powerful industrial lobby in Washington ${ }^{2}$ which tries to eliminates the competition, and the government who tries to maximize its revenue. The evidence for the government revenue maximization can be drawn by combining the figures of table 1 and table 2 . As one can see, table 2 assembles the data for imports for the twenty two products selected in table 1. Combining the figures of the two tables, one can see that there is a positive correlation between tariffs and import at gender level. In particular, for a specific gender, the higher is the import of a particular product relative to the other gender, the higher will be the tariff for that gender. We found that this is the case for fourteen products out of nineteen, (since no data are available for three products). The gender divergence between the import values of a particular product can be striking. For example, in the case of swimwear, the import for men is approximately $\$ 124$ million, while that for women is approximately $\$ 14$ million. Needles to say, the government's revenue is maximized if the tariff for men is much higher. An alternative way of analyzing this problem will be to look at the correlation between tariffs and the price elasticity of demand for each product selected. However, this alternative approach requires additional investigation given the extreme level of disaggregation of the data.

Table 1: Tariffs (Ad Valorem) on selected apparel and footwear products (2006)

\begin{tabular}{|c|c|c|c|}
\hline \multicolumn{4}{|c|}{ Apparel Knitted and Crocheted } \\
\hline Product & Women and Girls & Men and Boys & Difference \\
\hline Suits of synthetic fiber ( $>23 \%$ of wool and fine animal hair) & Free & $15.6 \%$ & -15.6 \\
\hline Suits of other synthetic fiber & $14.9 \%$ & $28.2 \%$ & -13.3 \\
\hline Jackets and Blazers of artificial fibers & $24 \%$ & $14.9 \%$ & 9.1 \\
\hline $\begin{array}{l}\text { Overcoats of other man-made fiber }(>23 \% \text { of wool and fine } \\
\text { animal hair) }\end{array}$ & $18.8 \%$ & $10 \%$ & 8.8 \\
\hline Suits of artificial fiber (>23\% of wool and fine animal hair) & $8.5 \%$ & Free & 8.5 \\
\hline $\begin{array}{l}\text { Jackets and Blazers of synthetic fiber ( }>23 \% \text { of wool and fine } \\
\text { animal hair) }\end{array}$ & $16.5 \%$ & $10 \%$ & 6.5 \\
\hline Jackets and Blazers of wool and fine animal hair & $16 \%$ & $10 \%$ & 6.0 \\
\hline \multicolumn{4}{|c|}{ Apparel Not Knitted and Crocheted } \\
\hline Swimwear of man-fiber & $11.8 \%$ & $27.8 \%$ & -16.0 \\
\hline Suits of other artificial fiber & $25.9 \%$ & $14.9 \%$ & 11.0 \\
\hline Shirts of silk or silk waste & $6.9 \%$ & $1.1 \%$ & 5.8 \\
\hline $\begin{array}{l}\text { Anoraks, Padded and Sleeveless Jackets of wool and fine } \\
\text { animal hair }\end{array}$ & $14 \%$ & $8.5 \%$ & 5.5 \\
\hline Underwear of cotton & $11.2 \%$ & $6.1 \%$ & 5.1 \\
\hline Bib and Brace Overalls of artificial fiber & $13.6 \%$ & $8.5 \%$ & 4.9 \\
\hline Underwear of man-made fiber and other materials & $14.9 \%$ & $10.5 \%$ & 4.4 \\
\hline Suits of artificial fiber (>36\% of wool and fine animal hair) & $17 \%$ & $21 \%$ & -4.0 \\
\hline Other Anoraks & $16.3 \%$ & $19.3 \%$ & -3.4 \\
\hline \multicolumn{4}{|c|}{ Footwear } \\
\hline Golf Shoes & $10 \%$ & $5 \%$ & 5.0 \\
\hline $\begin{array}{l}\text { Footwear with outer soles of rubber, plastic, leather and uppers } \\
\text { of leather }\end{array}$ & $10 \%$ & $8.5 \%$ & 1.5 \\
\hline Other Footwear made on a base or platform of wood & $10 \%$ & $8.5 \%$ & 1.5 \\
\hline Sport Shoes (tennis, basketball, gym) & $10 \%$ & $8.5 \%$ & 1.5 \\
\hline Parts of Footwear of leather or composition leather & $10 \%$ & $8.5 \%$ & 1.5 \\
\hline \multicolumn{4}{|c|}{ Articles of Leather } \\
\hline $\begin{array}{l}\text { Leather Gloves other than horsehide and cowhide lined and not } \\
\text { lined }\end{array}$ & $12.6 \%$ & $14 \%$ & -1.4 \\
\hline
\end{tabular}

Source: United States Harmonized Tariff Schedule

\footnotetext{
${ }^{2}$ On this issue see Andrejevic et. al. 2006.
} 
Table 2: Imports (value in thousands US dollars) on selected apparel and footwear products (2006)

\begin{tabular}{|c|c|c|c|}
\hline \multicolumn{4}{|c|}{ Apparel Knitted and Crocheted } \\
\hline Product & Women and Girls & Men and Boys & Difference \\
\hline Suits of synthetic fiber (>23\% of wool and fine animal hair) & 240 & N/A & N/A \\
\hline Suits of other synthetic fiber & 1,1229 & N/A & N/A \\
\hline Jackets and Blazers of artificial fibers & 10180 & 237 & 9,943 \\
\hline $\begin{array}{l}\text { Overcoats of other man-made fiber }(>23 \% \text { of wool and fine } \\
\text { animal hair) }\end{array}$ & 4,216 & 610 & 3,606 \\
\hline Suits of artificial fiber (>23\% of wool and fine animal hair) & 44 & N/A & N/A \\
\hline $\begin{array}{l}\text { Jackets and Blazers of synthetic fiber ( }>23 \% \text { of wool and fine } \\
\text { animal hair) }\end{array}$ & 4,251 & 110 & 4,141 \\
\hline Jackets and Blazers of wool and fine animal hair & 18,663 & 1,318 & 17,345 \\
\hline \multicolumn{4}{|c|}{ Apparel Not Knitted and Crocheted } \\
\hline Swimwear of man-fiber & 14,727 & 124,867 & $-110,140$ \\
\hline Suits of other artificial fiber & 22,755 & 4,089 & 18,666 \\
\hline Shirts of silk or silk waste & 345,799 & 147,175 & 198,624 \\
\hline $\begin{array}{l}\text { Anoraks, Padded and Sleeveless Jackets of wool and fine } \\
\text { animal hair }\end{array}$ & 414 & 577 & -163 \\
\hline Underwear of cotton & 725 & 226,064 & $-225,339$ \\
\hline Bib and Brace Overalls of artificial fiber & 235 & 139 & 96 \\
\hline Underwear of man-made fiber and other materials & 11,144 & 10,277 & 867 \\
\hline Suits of artificial fiber (>36\% of wool and fine animal hair) & 1,099 & 317 & 782 \\
\hline Other Anoraks & 42,481 & 44,994 & $-2,513$ \\
\hline \multicolumn{4}{|c|}{ Footwear } \\
\hline Golf Shoes & 18,594 & 73 & 18,521 \\
\hline $\begin{array}{l}\text { Footwear with outer soles of rubber, plastic, leather and uppers } \\
\text { of leather }\end{array}$ & 94,981 & 36,087 & 58,894 \\
\hline Other Footwear made on a base or platform of wood & 603,983 & 253,036 & 350,947 \\
\hline Sport Shoes (tennis, basketball, gym) & 916,075 & $1,098,591$ & $-182,516$ \\
\hline Parts of Footwear of leather or composition leather & 126 & 4,171 & $-4,045$ \\
\hline \multicolumn{4}{|l|}{$\begin{array}{ll} & \text { Articles of Leather }\end{array}$} \\
\hline $\begin{array}{l}\text { Leather Gloves other than horsehide and cowhide lined and not } \\
\text { lined }\end{array}$ & 10,268 & 85,092 & $-74,824$ \\
\hline
\end{tabular}

Source: US International Trade Commission

\section{POLICY RECOMMENDATIONS}

As mentioned in the introduction, the important issue of gender discrimination in the U.S. tariff system did not receive any attention in academic circles and very little attention in the media with the only exemption of Barbaro (2007). This is not the case in the business world. At the moment, few major apparel makers like Asics, Columbia Sportswear and Steve Madden are challenging the tariff system in lawsuits against the federal government. Their claim is that the different tariff rates for similar products based on gender represent a violation of the Constitution guarantee of due process and equal protection of the law. Hence, the tariff differentials constitute de jure gender discrimination ${ }^{3}$.

If the apparel makers win the case, the government will be obliged to pay one billion dollars as a compensation for tariff discrimination. For example, the lawsuit claims that in 2006 the government earned $\$ 2.5$ million from discriminatory tariffs on underpants (penalizing women); \$16 million on silk shirts (penalizing women) and \$71 million on shoes with leather tops (penalizing women) Barbaro (2007). The companies claim to charge equal price for similar men and women products. Consequently a discriminatory tariff represents a serious loss of money for the business community.

\footnotetext{
${ }^{3}$ Additional empirical evidence shows that tariffs on apparel and footwear for babies and infants do not differentiate between
} genders. 
The next problem here is the policy response of the federal government to the potential loss of the court case. Is the government going to eliminate gender differences by raising the lower tariffs or by reducing the higher ones? It is obvious that a conflict exists between the government's interest in raising the tariffs to maximize the revenue, and the companies' interest in lowering tariffs to maximize profits. Perhaps, this dilemma can be resolved by bringing the consumer into the picture which allows a more comprehensive approach. In our previous investigation, we found that tariffs on apparel and footwear act as a regressive taxation upon the poor because tariffs hit low income consumers which spend a disproportional percentage of their income on these products. People with the highest income i.e. $\$ 100,000$ (4.1\% of total population) spend $4.3 \%$ of their income on apparel and footwear, while the people with lowest level of income i.e. up to $\$ 9,999$ (9\% of the total population) spend $5.1 \%$ of their income on these products. Among the latter group, if we also consider those with income equal and less than $\$ 5,000$ the consumption of apparel and footwear goes up to 5.5\%. In other words, the poorer the person, the higher the proportion of his/her income spent on apparel and footwear, Andrejevic et. al (2006). Hence, this consideration brings an additional type of discrimination incorporated in the U.S. Tariff System: income discrimination.

Based on these two types of discrimination, the government should eliminate the gender differences in tariff, but also reduce their levels. There is no justification for gender difference of 16 percentage points for swimwear, as well as no justification for a low income consumer paying an ad valorem tariff of $32 \%$ on manmade fiber t-shirt when the average ad valorem tariff on all goods is $1.6 \%$.

\section{CONCLUSIONS}

In this paper we used a gender approach to study U.S. tariffs on selected apparel and footwear products. The scope of this paper was to examine whether gender played a role in evaluating the cost of tariffs on consumer and to suggest policies to end a possible discriminatory conduct. The main conclusions of the paper can be summarized as follows.

- $\quad$ Gender plays a role in the tariff system. In the case of footwear there is a limited pattern of divergence while in apparel, the gender difference is much higher and can reach extremely high figures.

- $\quad$ Out of the twenty two products examined, sixteen of them exhibit higher tariff for women indicating possible gender discrimination.

- $\quad$ The gender difference in tariff allows the government to maximize its revenue since the empirical evidence shows a positive correlation between tariffs and imports at gender level.

- Our policy recommendation for the government is not only to eliminate the gender divergence in the tariff, but also to lower their levels because in addition to the gender discrimination, there is an income discrimination incorporated in the U.S. Tariff System that needs to be addressed.

\section{REFERENCES}

1. Anderson, J., "The Relative Inefficiency of Quotas: The Cheese Case”, The American Economic Review, Vol. 75 (1), 1985, 178-90.

2. Andrejevic, U., G. Andreopoulos, and A. Panayides, "Tariffs on Necessities: Which Consumer Pays the Highest Bill?", Journal of Academy of Business and Economics, Vol. VI, Number 2, 2006.

3. Barbaro, M., "In Apparel, All Tariffs Aren’t Grated Equal”, New York Times, April 28, 2007.

4. Brook, W., and S. Magee, "The Economics of Special Interest Politics: The Case of the Tariff", The American Economic Review, Vol. 68 (2), 1978, 246-50.

5. $\quad$ Feenstra, R. C., "How Costly is Protectionism?", Journal of Economic Perspectives, Vol. 6 (3), 1992, 15978.

6. Gresser, E., "Toughest on the Poor: America's Flowed Tariff System”, Foreign Affairs, November/December 2002a.

7. Gresser, E., "Toughest on the Poor: Tariffs, Taxes, and the Single Mom”, Progressive Policy Institute, September 2002b.

8. Hitt, G., "How the Textile Industry Alone Won Quotas on Chinese Imports", The Wall Street Journal, November $10^{\text {th }} 2005$ 
9. Rodriguez, C. A., "The Quality of Imports and the Differential Welfare Effects of Tariffs, Quotas, and

Quality Controls as Protective Devices", The Canadian Journal Of Economics, Vol. 12 (3), 1979, 439-49.

10. US Census Bureau, www.census.gov

11. US International Trade Commission, Interactive Tariff and Trade DataWeb, http://dataweb.usitc.gov

\section{NOTES}

